\title{
Bricolage in Scientific Research Practice: An Attempt at Grasping the Meaning of the Concept
}

\begin{abstract}
The article presents the results of analyses aimed at capturing the significance of bricolage emerging from its uses in scientific research practice. The main point of my interest are scientific conceptualizations of the concept of bricolage relating to the practice of defining, characterizing and embedding its meaning in existing theoretical approaches. The empirical basis of the analysis is confined to a set of 47 scientific articles which contain the concept of bricolage in their titles, abstracts, and keywords. Collecting these articles involved searching through such bibliographic databases as Web of Science, Scopus, Wiley, and the Polish National Library Catalogue. The direction of the analysis was inductive and emergent, subordinated to such research issues as: 1 . what meanings of bricolage emerge from its use in scientific research practice? 2. how researchers justify the possibility of using bricolage in the practice of social and humanistic research? 3. what theoretical concepts are responsible for creating its meaning? Answering these questions has led me to a reconstruction of three conceptions of bricolage: epistemological bricolage, methodological bricolage, and hybrid bricolage.
\end{abstract}

Keywords:

bricolage, bricoleur, scientific research practice

\section{INTRODUCTION}

In 1959, Charles Percy Snow (1999) gave a lecture entitled The Two Cultures in the Senate Hall of Cambridge University. The state of scientific culture of the 1950s,

1 Department of Research Methodology and Discourse Studies, Kazimierz Wielki University in Bydgoszcz, Poland. E-MAIL: joteska@ukw.edu.plｏRCID: https://orcid.org/0000-0001-7870-7469 
as depicted by Snow, appeared fragmented into disciplines. While the "culture of natural scientists" was identified with "pure science”, maintaining the possibility of objective cognition, the "culture of intellectuals of literary provenance" was based on challenging those features which were constitutive for natural scientists.

The trends captured by Snow proved to be an accurate forecast of the development of Western scientific culture (see: Fleck, 1986; Kuhn, 2009). Its paradigmatic incommensurability (Lincoln \& Guba, 1985; Guba \& Lincoln, 2009) surfaced in methodological debate, described by Gage (1989) as the paradigm wars. According to Kenneth R. Howe (1992, p. 236), these wars were fought between the opposing factions of disjunctive eclecticism and methodological imperialism. While representatives of the first position emphasized equality among many paradigms, their opponents proclaimed the advantage of one paradigm over the others. The creative tension between them resulted in different concepts of knowledge and reality being investigated. Abstract and universal principles of methodology underwent significant contextualization, emphasizing the specificity of each scientific discipline and the perspectives used within it. Apart from experimentation and observation, new models of interpretation began to emerge, along with methods and techniques that form the strategy of qualitative research today. One of such models is bricolage.

The category of bricolage was introduced into international scientific circulation in the 1960s. Its theoretical complexity and methodological openness make it a rather controversial phenomenon, in need of careful assessment in terms of the profits and losses resulting from the tendency to assign to bricolage the status of a 'universal research concept' (see: Le Loarne, 2005; Johnson, 2012). One source of this controversy is the tension between methodological rigor (see: Saumure \& Given, 2008) and the possibility of its creative redefinition (cf. Hammersley, 1999; Kincheloe \& Berry, 2004; Kincheloe, 2011a). As Barbara van Mierlo and Edmond Totin claim (2014, pp. 157-158), the practice of bricolage can be compared to a theatrical performance:

while a script exists with prescription of how to perform, every live performance will turn out to be different, depending on the space in which the performers play and the interaction between the performers and their audience.

These remarkable difficulties in capturing the sense attributed to bricolage result, as I believe, both from its multi-theoretical background and from the research practice formed on its basis. It appears that the theoretical resources of bricolage contain the fundamental breakthroughs and tensions that have occurred in science over the past century. While the scientific genesis of the term bricolage refers to the work of Claude Lèvi-Strauss, the French cultural anthropologist and promoter of structuralism (see: 
Aduszkiewicz, 2004), its contemporary use is mainly connected with a qualitative search for multi-theoretical and multi-methodological foundations of scientific cognition (Kincheloe \& Berry, 2004; Denzin \& Lincoln, 2009a; Kincheloe, 2011b; Kincheloe \& McLaren, 2011). Thus, in a nutshell, it can be concluded that the metaphor of an epistemological bricoleur proposed by Lèvi-Strauss (1962) has evolved into a model of a qualitative researcher - a creator of patchworks, using any strategies, methods and empirical materials to understand and describe the world around her (Denzin et al., 2009 after Becker, 1998). If we add to this the tendency, which is noticeable in the scientific literature, to treat bricolage as a category of description (see: Weinstein \& Weinstein, 1991; Nelson, Treichler \& Grossberg, 1992; Ward, 2008), and if we take into account the plurality of its meanings resulting from the disciplinary contexts of the research conducted with it, the difficulties in developing a universal definition are hardly surprising. However, they ultimately contribute to identifying bricolage with irrational and chaotic action, associated with viewing the meaning of the concept as underdeveloped and unstable (see: Le Loarne, 2005; Visscher, Heusinkveld \& O’Mahoney, 2018).

For this reason, the primary purpose of this paper is to reconstruct the meanings ascribed to bricolage in the practice of scientific research. Its empirical exemplification here consists of a set of 47 scientific articles treating bricolage as a theoretical and practical problem. Analysis of the emergent meanings is subordinated to the assumptions of analytical induction, which makes it possible to consolidate the idiographic explanations made in the analytical material. Three concepts of bricolage were found to emerge, which contained the category of interest as the base: the processes of acquiring and processing knowledge (epistemological bricolage), the practice of multi-theoretical and multi-methodological scientific research (methodological bricolage), and a tool for comprehensive description of increasingly complex phenomena and objects (hybrid bricolage).

\section{PRINCIPAL ASSUMPTIONS}

The main intention of the presented analyses is to reconstruct the meanings attributed to bricolage in the practice of scientific research. By scientific research practice I mean here the conscious and purposeful activity of scientists aimed at producing data and information in a given field (see: Bauman, 2013; Rubacha, 2013). It results in making creations of scientific cognition that are varied in form, while the tools enabling their production are the rules of social and scientific research methodologies. According to Teresa Bauman (2013, p. 7), the area of scientific research prac- 
tice is co-created by such elements as: "meta-reflection on how to reach scientific knowledge, the theory that the researchers have at their disposal and use, the ways in which they carry out their own research projects and the results of their research". It follows that the process of its reconstruction may correspond to a broad or narrow understanding of scientific research (see: Apanowicz, 2002, p. 19).

Reflection on research in a broad sense covers all stages of a study, from the decision to consider a specific issue to its written elaboration. Focusing on the sequential activities of the researcher allows tracing the process of creating the object of analysis depending on the decisions made and the conditions of implementing a specific project. Scientific research understood narrowly limits the reconstructor's attention to selected activities carried out as part of a specific stage of the study. It follows that the meaning of bricolage that emerges from the practice can be captured statically, as a specific result of scientific cognition, or dynamically, taking into account the process that led to its creation.

The considerations in this article are confined to this narrow understanding, and the emergent meaning of bricolage can be presented statically as one of the elements of knowledge produced about it. My chief interest are the scientific conceptualizations of the concept of bricolage, by which I mean the practice of defining, characterizing and embedding categories in specific theoretical traditions. Reconstruction here consists in reporting, and it aims to recreate the most important elements of meanings that are found to be rooted in the linguistic intuition of specific disciplines of science (see: Sztompka, 1973).

The empirical basis of my analyses will be confined to a set of 47 articles published in English and Polish peer-reviewed journals with strict requirements as to adherence to the principles of research writing in creative elaboration of a selected issue (cf. the Ordinance of the Minister of Science and Higher Education of February 22, 2019). The process selection was based on specific criteria and occurred in two stages: external and internal (see: Flick, 2010).

The external selection was connected with exploring bibliographic databases in the area of social sciences and humanities and the National Library Catalog (see: Table 1). According to Aneta Drabek (2018), the databases used in the exploration phase are an accurate and reliable tool for searching through source literature, gathering articles from thousands of journals within a single searchable data bank. The records obtained are stable, and bibliometric procedures performed on them reflect the prestige and scientific correctness of each article. The reason for exploring the National Library Catalog was that it contains articles on topics of interest to me. Exploration of such databases as ERIH, BazEkon, Pedagogue and CEJSH yielded no results. 
Table 1. Numerical Breakdown of the Results of Searching through Bibliographic Databases

\begin{tabular}{|l|c|c|}
\hline \multicolumn{1}{|c|}{ Database } & $\begin{array}{c}\text { Number of records found } \\
\text { in open access mode }\end{array}$ & $\begin{array}{c}\text { Number of articles included } \\
\text { in the analysis }\end{array}$ \\
\hline Scopus & 30 & 28 \\
\hline Wiley & 34 & 10 \\
\hline Web of Science & 43 & 6 \\
\hline National Library Catalog & 11 & 3 \\
\hline
\end{tabular}

Source: the author's own elaboration.

Entering such phrases as bricolage and bricoleur into the search engine revealed such products of scientific research which in their title, abstract, or keywords contained the category that was of interest to me. Nevertheless, scanning these articles showed that often despite the words bricolage or bricoleur being used in the paratextual elements (cf. Bulisz, 2017), they did not always occur in the body text of the article. For this reason, in the final analysis I only included those articles to which access was provided in their entirety, and the category of bricolage appeared more than ten times in the entire text. It follows that the body of materials ultimately generated in this way does not meet the criterion of external representativeness (see: Flick, 2010), and the idiographic explanations produced on its basis retain their validity only for the articles presented in Table 2 (see: Appendix 1).

Internal material selection was as a prelude to the analysis proper. Thematic organization of the materials was preceded by an analysis of the objects and objectives of each study declared in the articles. Then the selected materials were grouped into smaller subsets, representing the practice of using bricolage in products of scientific research (see: Figure 1).

Figure 1. Contexts of Occurrence of the Notion of bricolage in the Analyzed Corpus

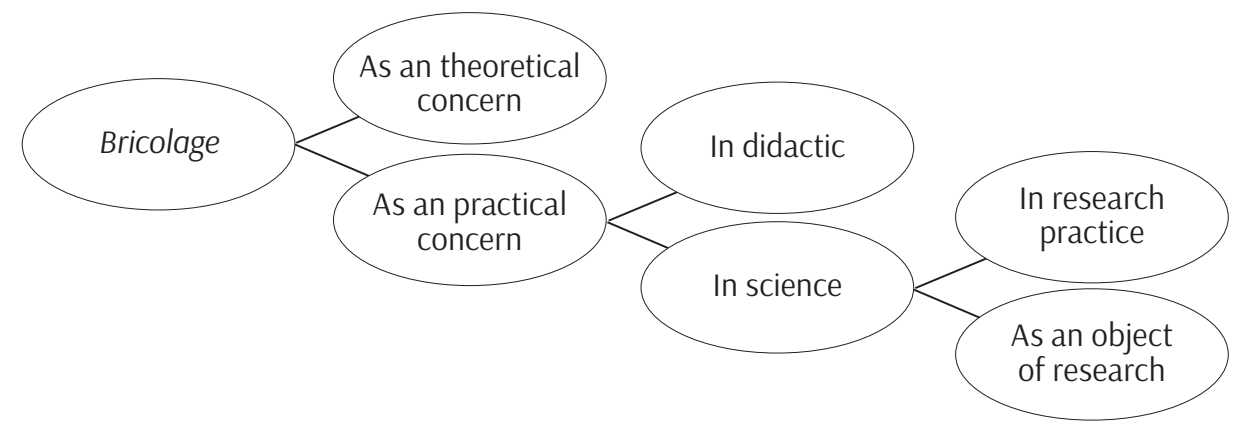

Source: the author's own elaboration. 
As can be inferred from the above diagram, bricolage functions as a theoretical and practical problem in these articles (see: Lincoln, 2001). Their authors either attempt to develop the meaning of bricolage theoretically, or present the effects of studies carried out by means of bricolage or with bricolage as an object of study.

In the articles which presented bricolage as a theoretical problem, the conceptualization of bricolage was reduced to such procedures as 1. analyzing the multidisciplinary theoretical concepts describing and explaining the meaning of bricolage, 2. an in-depth description of the context of its introduction to social sciences and the humanities, and 3. justifying its applicability to research by considering its benefits and problems.

As a practical problem, bricolage was presented from a scientific and didactic perspective. The articles that included it were study reports taking the form of a reflexive account of the research procedure followed or its faithful reproduction, along with a detailed description of the results obtained. Considerations on bricolage from the didactic perspective were reduced to the relation between academic teachers and students. Their direct basis was the process of shaping methodologies, aimed at providing students with more critical and sensitizing tools to understand the world around us (Kaomea, 2016). As one possible research perspective, bricolage was presented in the context of not always laudable aspects of qualitative research, reconstructed from the perspective of colonialism and indigenous research. Concern about hearing the voices of historically marginalized and excluded communities obligates future adepts of education research to develop a multi-theoretical and multi-methodological toolbox that introduces the postulate of social justice into research practice. A description of the process of its construction, supported by the educational experience of the authors, thus answers the question about the possibility of learning bricolage. The resulting knowledge is practical and can be used in the territorially and culturally heterogeneous context of academic education.

My analysis covered previously encoded fragments of articles derived both from their paratextual elements (the title, abstract, author's affiliation, publication date) and from the main text (see: Bulisz, 2017). The codes emerged inductively and comprised the following set of categories: bricolage, bricoleur, bricolage features, bricolage functions, bricolage definitions, bricolage terms, theoretical conceptions and the context of origin. My analysis was guided by such research problems as 1 . What meanings of bricolage emerge from the research practice that uses this notion? 2. How do the researchers justify the possibility of using it in the practice of social studies and research within the humanities? 3. What theoretical concepts are responsible for creating its meaning? Answering these questions has led me to a reconstruction of three conceptions of bricolage: epistemological brico- 
lage, methodological bricolage, and hybrid bricolage. Their description is preceded by a presentation of analyses related to the context in which bricolage functions in scientific research practice.

\section{RESULTS}

The analysis of the paratextual elements of the selected research reports revealed that the category of bricolage is used with success in international research in the social sciences, the humanities, and health sciences. The researchers using it represent as many as five continents and 67 institutions of science and higher education. Such a wide distribution of the articles at the time of their publication shows a significant increase of interest in bricolage (see: Figure 2).

Figure 2. Distribution of the Analyzed Articles According to Their Time of Publication

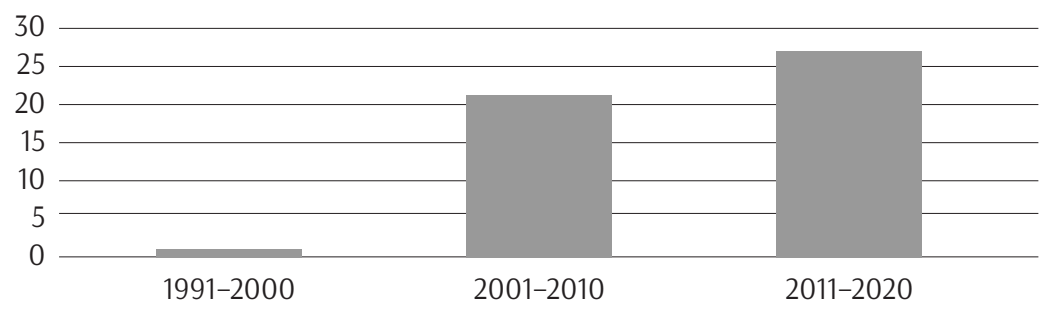

Source: the author's own elaboration.

While in the 1990s only one such article was published, in the first decade of the 2000s their number rose to 20 and in the second to 26. It is possible that the quantitative increase in publications noted here results from the popularization of the assumptions of postmodernism, which - according to Papson (2014, p. 388) - is the home of bricolage. The experience of the fall of previous meta-narratives, fragmentation of knowledge, pluralization of truths, as well as functioning in hyper-reality in which "illusion and simulation are valued more than the underlying objects” (Valliere \& Gegenhuber, 2014, p. 7) have been posing a challenge for contemporary academia and the research methods that it recommends (see: Bush \& Silk, 2010; Papson, 2014). The limitations perceived by researchers due to the dominance of "orthodox positivist approaches" (Turnbull, 2002, p. 11; Nyika \& Murray-Orr, 2017), along with the conviction that the development of research methods is too slow in relation to the rapid changes of the objects studied using these methods has triggered the need to search for "multitheoretical, 
multimethodological and multidisciplinary informed approaches to methodological decisions making” (McMillan, 2015, p. 1). Thus, the bricolage that stems from the assumptions of postmodernism is understood as "a functional response to both the increasing velocities of information and the breakdown of cultural hierarchies" (Papson, 2014, p. 377). It is “a creative act as it involves tactful and creative appropriation, orchestration and transformation of all sorts of cultural texts which are at hand" (Tam, 2012, p. 245). Those bricoleurs who practice it become cognitive activists (Earl, 2017) and cognitive mediators in the process of boldly breaking the existing status quo. Their reflectiveness is rooted in various contexts and theoretical concepts that give bricolage the form of an intellectual hybrid. My analyses have led me to distinguish three basic concepts of bricolage, differing in their degrees of organization of the content presented in them, the theoretical backgrounds used, as well as their purpose. Detailed characteristics of epistemological, methodological and hybrid bricolage are presented later in the article.

\section{EPISTEMOLOGICAL BRICOLAGE}

The conception of epistemological bricolage is confined to reflections on knowledge. The possibilities of acquiring knowledge, its transformation, and what follows - its practical use - are characterized as the subtle task of "piecing together, assembling and literally making sense of different bits of information and experience, often creating something new from what they [bricoleurs] have acquired secondhand" (Freeman, 2007, p. 476). This task is undertaken in the context of postmodernism. Functioning in a world that is constantly changing, digitized and overflowing with enormous amounts of more or less significant information makes bricoleurs best suited to the requirements of modern times. Bricolage as an orientation toward fragmented and fleeting knowledge arriving from multiple sources "allows for a creative playfulness. Through incongruous juxtaposition it constantly extends itself beyond boundaries. Loose allusion opens up channels of interpretation limited by more rigorous analysis” (Papson, 2014, p. 388).

Epistemological bricolage thus corresponds to the characteristics of mythical thinking, which is the basis for the functioning of the bricoleur in Claude Lèvi-Strauss' theory (1962). Raffi Duymedjian and Charles Clemens Rüling (2010, p. 137) claim that the methods of conduct emerging from the pages penned by the French structuralist refer to three basic aspects: repertoire, dialogue, and final effect. Repertoire defines the overall collection of the objects and materials gathered according to the principle: "this may come in handy" at some point. Their resources are always limited. As Claude Lèvi-Strauss claims (1962), the 
first practical actions of the bricoleur are always retrospective and relative to the existing stock of tools and data. Understanding these objects, taking stock of them or displacing them in their present arrangement requires the formation of a dialogic relationship. The logic of mythical thinking, rooted in the widely understood resources of culture such as art, architecture, magic or poetry, results from the reversed order of cognition:

To understand a real object in its totality we always tend to work from its parts. The resistance it offers us is overcome by dividing it. Reduction in scale reverses this situation. Being smaller, the object as a whole seems less formidable. By being quantitatively diminished, it seems to us qualitatively simplified. More exactly, this quantitative transposition extends and diversifies our power over a homologue of the thing, and by means of it the latter can be grasped, assessed and apprehended at a glance (Lèvi-Strauss, 1962, p. 16).

The final effect developed on its basis is referred to as the "reduced model", which is the equivalent of coming into real contact with the object. Its formula is permanently open and ultimately unfinished, because a problem always has many solutions:

The choice of the solution involves the modification of the result to which another solution would have led, and the observer is in effect presented with general picture of these permutations at the same time as the particular solution offered. He is thereby transformed into an active participant without even being aware of it (Lèvi-Strauss, 1962, p. 16).

Intellectual bricolage is thus a kind of mythical thinking that synthesizes, analyzes, arranges or complicates selected objects due to the purpose of cognition that is selected. Therefore it does not belong to the domain of science: there is a distinction between "the scientist creating events (changing the world) by means of structures and the 'bricoleur' creating structures by means of the events" (Lèvi-Strauss, 1962, p. 15). The disjunction of perspectives on cognition signaled in this conception was emphasized by comparing the work of a bricoleur to that of an engineer who:

has to begin by making a catalogue of a previously determined set consisting of theoretical and practical knowledge, of technical means, which restrict the possible solutions (Lèvi-Strauss, 1962, p. 13).

His conduct, based on the distinction between what is incidental and what is necessary excludes, therefore, the possibility of a dialogic understanding of objects. It is always contingent on a limited collection of raw materials and tools reflecting the structures created in science, rather than on the direct object of cognition.

Thus, cognitive bricoleurs are all individuals who demonstrate the ability to process and use knowledge reflectively. They are students and teenagers no 
longer uncomfortable with the "sampling, ripping, masking and remixing" of the information that is bombarding them (Papson, 2014, p. 387). They are political decision-makers functioning in heterogeneous epistemological domains, based on intuition, practical sense, obtaining information from others and from the environment (Freeman, 2007). They are also representatives of companies and organizations. The phenomenon of "organizational memory" that occurs among them allows them to "maintain an inductively generated knowledge base founded on experience” (Duymedjian \& Rüling, 2010, p. 135). Bricolage is thus a form of collective action based on familiarity and conventional utility regimes. While the former emphasizes the possibility of individual "dialogue” with the recognized material, the latter is based on local conventions which "create the inter-subject order needed to regulate the use of the same space by actors who are not present at the same time, and who have been able to develop similar familiarity with object in the common space” (Duymedjian \& Rüling, 2010, p. 144).

Thus, epistemological bricolage answers the questions: how do I know that I know and how the supposition that I know determines the possibility of action taken in practice.

\section{METHODOLOGICAL BRICOLAGE}

Reflections on the possibility of using bricolage in the practice of qualitative research were embedded in the convention of reflexive accounts of the research procedures followed. Therefore, the authors of the articles shared their experiences gathered on the "methodological and ontological journeys" (Turnbull, 2002, p. 111) they took on the occasion of pursuing a specific research project. Detailed characteristics of the results of the studies give way here to in-depth, sometimes autobiographical descriptions of the research procedures followed, the methods of data collection and analysis used within its framework, the positions taken by the researcher and the possibilities of producing socially engaged knowledge, resulting in changes in current social policies, education (Kawecki, 2006; SadońOsowiecka, 2009; McMillan, 2015; Earl, 2017; Nyika \& Murray-Orr, 2017), and selected areas of science (Turnbull, 2002).

A rejection of deterministic visions of social reality, promotion of reflectiveness, and an attitude of respect for "heterogeneous points of view" have turned research into an art of making conscious choices, obligating the researcher "to participate in the formation of new struggles, rather than follow the old methods" (Earl, 2017, p. 130). The epistemology of complexity (see: Kincheloe \& Berry, 2004), and the need for Complex Inquiry Approach (McMillan, 2015), as declared by the authors, has forced the researchers-bricoleurs to stay away from methodo- 
logical guides produced outside the specific requirements of the object of inquiry. Scientific DIY therefore refers to bold combinations of paradigms (critical theory, constructivism and participation; see: Guba \& Lincoln, 2009) with their associated theoretical and methodological backgrounds. The metaphor of research as bricolage in the analyzed publications (Turnbull, 2002, p. 111) refers to the assumptions of critical bricolage and social constructivism.

The theoretical conceptualization of critical bricolage is based on the work of the Canadian promoter of critical pedagogy, Joe L. Kincheloe, and the conception of qualitative research developed by Ivonne Lincoln and Norman Denzin (2009a). Scientific DIY is understood as a highly advanced process, including construction, reconstruction, context diagnosis, negotiation, and readiness to reconsider the legitimacy of the propositions generated. The reality diagnosed on its basis is characterized by multiple complexities. Understanding it becomes possible only after taking into account the context of the study and the impact of its background assumptions on the final effect. The relation between the researcher and the object of the study is therefore always complicated and unpredictable. For this reason, the researcher-bricoleur "is far more skilled than merely a handyman. This bricoleur looks for not yet imagined tools, fashioning them with not yet imagined connections" (Lincoln, 2001, p. 693). Focusing on what is absent and invisible at first glance, subordinating interpretation to categories of discourse and context, taking into account the discursive construction of power and the struggle to generate particular meanings, as well as evading determination of the truth on the basis of empirical research - these are but a few of the skills that are part of the workshop of the critical bricoleur. His reflectiveness is rooted in the tradition of critical theory, but it does allow the possibility of incorporating in its assumptions concepts located in other theoretical traditions:

Does this suggest that bricoleurs might come in two distinct forms: those who are committed to methodological eclecticism, permitting the scene and circumstance and presence or absence of core searchers to dictate method, and those whose function is to engage in a genealogy archaeology of the disciplines with some larger purpose than ethnography in mind? (Lincoln, 2001, pp. 694-695).

In the collection of publications analyzed, critical reflectiveness of Paulo Freire, Antonio Gramsci, Jürgen Habermas, Chantal Mouffe, and Michel Foucault is combined with the assumptions of social constructivism in Kenneth Gergen's or Lew Wygotski's view, with the conception of research in action, feminist studies and indigenous research. In this way, the perceived limitations of a single paradigm are creatively eliminated, and bricolage becomes a tool for creating new theoretical foundations for research. 


\section{HYBRID BRICOLAGE}

Hybrid bricolage has its source in the complex life practice based on the cacophony of lived experiences, heterogeneous senses and meanings with divergent interpretations. Describing and understanding them is thus made possible thanks to the practice of creating differentiated meanings of bricolage, referring to the context of the study. Among the issues declared in the publications, there were such research subjects as:

- innovation, non-standardization and effectiveness of entrepreneurial activity (Baker \& Nelson, 2005; Desa, 2012; Fisher, 2012; Stinchfield, Nelson \& Wood, 2013, Illia \& Zamparini, 2016);

- $\quad$ the practice of making decisions on the choice of therapeutic strategies (Hester, 2005; Broom, 2009), dietary preferences (Cronin \& Malone, 2018), gender and race-differentiated consumer and health-promoting behaviour (Russell \& Tyler, 2005), decision making in organizational environments (Daipha, 2015);

- providing healthcare in heterogeneous cultural, social, economic and political ecosystems of needs and expectations (Phillimore et al., 2018);

- shaping both individual and collective religious identity (Saroglou, 2006; Christians, 2006) or the identity of football club members (Gutu, 2017);

- economical aspects of international tourism (Baláž \& Williams, 2005), geography of death and dying (Madge, 2017);

- $\quad$ creating a group culture for children in the course of a sociodramatic play (Tam, 2012).

All the many different meanings of bricolage are being created here each time according to the needs of a specific project, although the invariant feature of almost all the approaches is the emphasis they put on the relationship between knowledge, action, and the contexts of their creation. Since reality is ambiguous and ever-changing, it forms increasingly complicated and cognitively demanding phenomena. For this reason, I take the fact that as many as fourteen adjectives ${ }^{2}$ and eight attributive nouns ${ }^{3}$ were found to modify bricolage in these publications as an illustration of the creative need to search for new perspectives and, conse-

2 Institutional bricolage, entrepreneurial bricolage, historical bricolage, religious bricolage, intellectual bricolage, critical bricolage, moral bricolage, collective bricolage as familiar bricolage and convention based bricolage, autobiographical bricolage, epistemological bricolage, social constructivism bricolage, social bricolage.

3 Bricolage as a concept, entrepreneurial behavior, "as an approach to theory building” the metaphor of research activity, act of identity, the orientation to knowledge, a process, a creative act. 
quently, to compile a new language for describing the phenomena under scientific scrutiny. Religious bricolage is therefore a response to the need to exist in diverse if not disparate religious traditions (Saroglou, 2006; Christians, 2006). Providing medical services in increasingly complex political, economic and social arrangements makes bricolage a basic mechanism of action, one which enables "solving problems on the spot by resources at hand” (Krontoft, Fuglsang \& Kronborg, 2018, p. 151). The practice of non-standard entrepreneurial behavior has led to the concept of entrepreneurial bricolage, characterized by such properties as:

- making do, understood as a refusal to succumb to restrictions resulting from commonly accepted practices, standards and definitions of materials to use;

- combining and recombining resources to solve problems efficiently and unconventionally;

- 'collecting together 'bits and pieces' that may come in handy at some future point” (Phillips \& Tracey, 2007, pp. 316-317).

Institutional bricolage in turn answers the question "how mechanisms for resource management and collective action are borrowed or constructed from existing institutions, styles of thinking and sanctioned social relationships” (Cleaver, 2001, p. 29). The examples presented above, although they do not exhaust the entire spectrum of approaches in the discussed articles, show that the bricolage is an effective tool for describing increasingly complex phenomena and objects.

\section{CONCLUSION}

The deliberations presented here are a result of specific organizational and conceptual procedures aimed at lending credibility to the necessity to reflect more deeply on the status of bricolage in science. They come from a preliminary study of the analyzed material, limited both in scope and thematic complexity. Their reception should therefore proceed with caution and sensitivity to the fact that they do not meet the requirement of external representativeness, limiting the possibility of generalizing the conclusions generated on their basis only to articles listed in Appendix.

Thus, abandoning the tendency to push for "solely valid explanations", I see the fundamental usefulness of the analyses as an opportunity to rethink bricolage. Out of the concepts derived from it, only hybrid bricolage retains the features of the ambiguous, meaningless, unstable and chaotic concept typically attributed to it. However, the practice of thinking up atomized meanings which do not contrib- 
ute to the creation of a picture of the whole is justified by the need to cognitively tame the increasingly less homogenous and less predictable objects of study. The polysemy of bricolage is therefore not merely acceptable here - rather than that, it constitutes for the bricoleur an essential rule for giving an account of the world in its non-reducible multiplicity. In this sense, to insist on the creation of a universal definition of bricolage would mean a denial of the constitutive values of the approach in question, which are committed to the need to accept otherness, incompatibility, to distinguish oneself from the rest.

For epistemological and methodological bricolage, the element limiting the freedom of semantic practices is the specific theoretical basis, referring to the work of Claude Lèvi-Strauss, Joe L. Kincheloe, Ivonne S. Lincoln, and Norman Denzin. Concepts formed on their basis oscillate around the need to produce, process and distribute knowledge corresponding to the action and context of their occurrence. Its point of departure are therefore references to the existing set of concepts and perspectives at hand, and the end point are innovative and non-standard models of methodological action. Innovative readings of already well-known texts, and their bold combination with other perspectives and research possibilities make bricolage a tool for thinking creatively about what is not yet there, what is only coming and posing challenges to scientific taming of the world. The reconstruction of the conceptual space proposed by bricolage, therefore, sheds entirely new light on the simplicity and predictability of scientific research. Understanding its sources, heterogeneous shades and tendencies to split seems to be a prerequisite for conscious use of bricolage in the practice of scientific research.

\section{References}

Aduszkiewicz, A. (2004). Słownik filozofii. Warszawa: Świat Książki.

Apanowicz, J. (2002). Metodologia ogólna. Gdańsk: Wydawnictwo Diecezji Pelplińskiej „Bernardinum”.

Baker, T., \& Nelson, R.E. (2005). Creating Something from Nothing: Resource Construction through Entrepreneurial Bricolage. Administrative Science Quarterly, 50(3), pp. 329-366. DOI: 10.2189/asqu.2005.50.3.329.

Baláž, V., \& Williams, A.M. (2005). International Tourism as Bricolage: An Analysis of Central Europe on the Brink of European Union Membership. International Journal of Tourism Research, 7(2), pp. 79-93. DOI: 10.1002/jtr.514.

Bauman, T. (Ed.). (2013). Praktyka badań pedagogicznych. Kraków: Oficyna Wydawnicza Impuls.

Becker, H.S. (1998). Tricks of the Trade. How to Think about Your Research while You're Doing It? Chicago. University of Chicago Press. 
Broom, A. (2009). Intuition, Subjectivity, and Le Bricoleur: Cancer Patients' Accounts of Negotiating a Plurality of Therapeutic Options. Qualitative Health Research, 19(8), pp. 1050-1059. DOI: 10.1177/1049732309341190.

Bulisz, E. (2017). O artykule naukowym słów kilka. Progress: Journal of Young Researchers, 1, pp. 13-21. DOI: 10.4467/25439928PS.17.001.6507.

Bush, A., \& Silk, M. (2010). Towards an Evolving Critical Consciousness in Coaching Research: The Physical Pedagogic Bricolage. International Journal of Sports Science \& Coaching, 5(4), pp. 551-565. DOI: 10.1260/1747-9541.5.4.551.

Christians, L.L. (2006). Religious Bricolage in a Legal Perspective between Aporia and Inescapability. Social Compass, 53(1), pp. 117-123. DOI: $10.1177 / 0037768606061582$.

Cleaver, F. (2001). Institutional Bricolage, Conflict and Cooperation in Usangu, Tanzania. IDS Bulletin, 32(4), pp. 26-35.

Cochran, E.A. (2012). Bricolage and the Purity of Traditions. Engaging the Stoics for Contemporary Christian Ethics. Journal of Religious Ethics, 40(4), pp. 720-729. DOI: 10.1111/ j.1467-9795.2012.00545.x.

Cronin, J., \& Malone, S. (2018). Lifeway Alibis: The Biographical Bases for Unruly Bricolage. Marketing Theory, 19(2), pp. 129-147. DOI: 10.1177/1470593118787587.

Daipha, P. (2015). From Bricolage to Collage. The Making of Decisions at a Weather Forecast Office. Sociological Forum, 30(3), pp. 787-808. DOI: 10.1111/socf.12192.

Denzin, N.K., \& Lincoln, Y.S. (Eds.). (2009). The Sage Handbook of Qualitative Research Methods ( $3^{\text {rd }}$ Ed.). Los Angeles-London-New Delhi-Singapore-Washington DC: Sage Publications.

Denzin, N.K., \& Lincoln, Y.S. (2009a). Introduction. The Discipline and Practice of Qualitative Research. In: N.S. Denzin, \& Y.S. Lincoln (Eds.), The Sage Handbook of Qualitative Research Methods ( $3^{\text {rd }}$ Ed.) (pp. 1-32). Los Angeles-London-New Delhi-SingaporeWashington DC: Sage Publications.

Desa, G. (2012). Resource Mobilization in International Social Entrepreneurship: Bricolage as a Mechanism of Institutional Transformation. Entrepreneurship Theory and Practice, 36(4), pp. 727-751. DOI: 10.1111/j.1540-6520.2010.00430.x.

Di Domenico, M.L., \& Haugh, H. (2010). Social Bricolage: Theorizing Social Value Creation in Social Enterprises. Entrepreneurship Theory and Practice, 34(4), pp. 681-703. DOI: 10.1111/j.1540-6520.2010.00370.x.

Drabek, A. (2018). Indeksowanie czasopism w referencyjnych bazach danych. Poradnik dla wydawców czasopism. Poznań: UAM.

Duymedjian, R., \& Rüling, Ch.C. (2010). Towards a Foundation of Bricolage in Organization and Management Theory. Organization Studies, 31(2), pp. 133-151. DOI: 10.1177/01708 40609347051.

Earl, C. (2017). The Researcher as Cognitive Activist and the Mutually Useful Conversation. Power and Education, 9(2), pp. 129-144. DOI: 10.1177/1757743817714281.

Fisher, G. (2012). Effectuation, Causation and Bricolage: A Behavioral Comparison of Emerging Theories in Entrepreneurship Research. Entrepreneurship Theory and Practice, 36(5), pp. 1019-1051. DOI: 10.1111/j.1540-6520.2012.00537.x.

Fleck, L. (1986). Powstanie i rozwój faktu naukowego. Wprowadzenie do nauki o stylu myślowym i kolektywie myślowym. Lublin: Wydawnictwo Lubelskie.

Flick, U. (2010). Projektowanie badania jakościowego. Warszawa: WN PWN. 
Freeman, R. (2007). Epistemological Bricolage: How Practitioners Make Sense of Learning. Administration \& Society, 39(4), pp. 476-496. DOI: 10.1177/0095399707301857.

Gage, N.L. (1989). The Paradigm Wars and Their Aftermath: A “Historical” Sketch of Research on Teaching since 1989. Educational Researcher, 18(7), pp. 4-10. DOI: 10.3102/001318 9X018007004.

Guba, E.G., \& Lincoln, Y.S. (2009). Paradigmatic Controversies, Contradictions, and Emerging Confluences. In: N.S. Denzin, \& Y.S. Lincoln (Eds.), The Sage Handbook of Qualitative Research Methods ( ${ }^{\text {rd }}$ Ed.) (pp. 191-216). Los Angeles-London-New Delhi-Singapore-Washington DC: Sage Publications.

Guo, Z., Zhang, J., \& Gao, L. (2018). It Is Not a Panacea! The Conditional Effect of Bricolage in SME Opportunity Exploitation. R\&D Management, 48(5), pp. 603-614. DOI: 10.1111/ radm.12325.

Gutu, D. (2017). Casuals’ Culture: Bricolage and Consumerism in Football Supporters' Culture. Case Study - Dinamo Bucharest Ultras. Soccer \& Society, 18(7), pp. 914-936. DOI: 10.1080/14660970.2015.1067794.

Hammersley, M. (1999). Not Bricolage but Boatbuilding: Exploring Two Metaphors for Thinking about Ethnography. Journal of Contemporary Ethnography, 28(5), pp. 574-585. DOI: 10.1177/089124199129023569.

Hester, J.S. (2005). Bricolage and Bodies of Knowledge: Exploring Consumer Responses to Controversy about the Third Generation Oral Contraceptive Pill. Body \& Society, 11(3), pp. 77-95. DOI: 10.1177/1357034X05056192.

Howe, K.R. (1992). Getting Over the Quantitative-Qualitative Debate. American Journal of Education, 100(2), pp. 236-257.

Illia, L., \& Zamparini, A. (2016). Legitimate Distinctiveness, Historical Bricolage, and the Fortune of the Commons. Journal of Management Inquiry, 25(4), pp. 397-414. DOI: $10.1177 / 1056492616637917$.

Johnson, Ch. (2012). Bricoleur and Bricolage: From Metaphor to Universal Concept. Paragraph, 35(3), pp. 355-371. DOI: 10.3366/para.2012.0064.

Kaomea, J. (2016). Qualitative Analysis as Ho'oku'iku'i or Bricolage: Teaching Emancipatory Indigenous Research in Postcolonial Hawai'i. Qualitative Inquiry, 22(2), pp. 99-106. DOI: $10.1177 / 1077800415620222$.

Kawecki, I. (2006). „Bricolage” w metodologii jakościowych badań edukacyjnych. Prace Naukowe AJD. Pedagogika, 15, pp. 53-62.

Kincheloe, J.L. (2011a). Describing the Bricolage: Conceptualizing a New Rigor in Qualitative Research. In: K. Hayes, S.R. Steinberg, \& K. Tobin (Eds.), Key Works in Critical Pedagogy (pp. 177-190). Rotterdam-Boston-Taipei: Sense Publishers.

Kincheloe, J.L. (2011b). On to the Next Level: Continuing the Conceptualization of the Bricolage. In: K. Hayes, S.R. Steinberg, \& K. Tobin (Eds.), Key Works in Critical Pedagogy (pp. 253-278). Rotterdam-Boston-Taipei: Sense Publishers.

Kincheloe, J.L., \& Berry, K. (2004). Rigour and Complexity in Educational Research: Conceptualizing the Bricolage. Berkshire: Open University Press.

Kincheloe, J.L., \& McLaren P. (2011). Rethinking Critical Theory and Qualitative Research. In: K. Hayes, S.R. Steinberg, \& K. Tobin (Eds.), Key Works in Critical Pedagogy (pp. 285-326). Rotterdam-Boston-Taipei: Sense Publishers. 
Krontoft, A., Fuglsang, L., \& Kronborg, H. (2018). Innovation Activity Among Nurses: The Translation and Preliminary Validation of the Bricolage Measure - A Mixed-Method Study. Nordic Journal of Nursing Research, 38(3), pp. 151-159. DOI: 10.1177/2057158517733931.

Kuhn, T. (2009). Struktura rewolucji naukowych. Warszawa: Aletheia.

Laurent, P.J. (2005). The Process of Bricolage Between Mythic Societies and Global Modernity: Conversion to the Assembly of God Faith in Burkina Faso. Social Compass, 52(3), pp. 309-323. DOI: 10.1177/0037768605055648.

Le Loarne, S. (2005). Bricolage versus Creativity. What's the Difference? Working Paper Serie RMT (WPS 05-02), Grenoble Ecole de Management. Retrieved from: https://pdfs. semanticscholar.org/91b9/2e3dcb664b81c845e9e97dc2127758cccd85.pdf?_ga=2.15049 0164.384015683.1590595109-2104313570.1590083755.

Lèvi-Strauss, C. (1962). The Science of the Concrete. In: C. Lèvi-Strauss, The Savage Mind (pp. 1-22). Chicago: University of Chicago Press.

Lincoln, Y.S. (2001). An Emerging New Bricoleur: Promises and Possibilities - A Reaction to Joe Kincheloe’s “Describing the Bricoleur”. Qualitative Inquiry, 7(6), pp. 693-696. DOI: 10.1177/107780040100700602.

Lincoln, Y., \& Guba, E. (1985). Naturalistic Inquiry. Los Angeles-London-New Delhi-Singapore: Sage.

Liu, J. (2019). Ideal Identity Arises from Bricolage: Identity Issues in Patrick White's 'The Twyborn Affair’. Comparative Literature: East \& West, 3(1), pp. 68-78. DOI: 10.1080/2 5723618.2019.1614845.

MacKenzie, D., \& Pardo-Guerra, J.P. (2014). Insurgent Capitalism: Island, Bricolage and the Re-making of Finance. Economy \& Society, 43(2), pp. 153-182. DOI: 10.1080/03085147 .2014.881597.

Madge, C. (2017). Creative Geographies and Living on from Breast Cancer: The Enlivening Potential of Autobiographical Bricolage for an Aesthetics of Precarity. TIBG, 43(2), pp. 245-261. DOI: 10.1111/tran.12215.

McMillan, K. (2015). The Critical Bricolage: Uniquely Advancing Organizational and Nursing Knowledge on the Subject of Rapid and Continuous Change in Health Care. International Journal of Qualitative Methods, 14(4), pp. 1-8. DOI: 10.1177/1609406915611550.

Nelson, C., Treichler, P.A., \& Grossberg L. (1992). Cultural Studies. An Introduction. In: L. Grossberg, C. Nelson, \& P.A. Treichler (Eds.), Cultural Studies (pp. 1-16). New York: Routledge.

Nyika, L., \& Murray-Orr, A. (2017). Critical Race Theory-Social Constructivist Bricolage: A Health-Promoting Schools Research Methodology. Health Education Journal, 76(4), pp. 432-441. DOI: 10.1177/0017896916689108.

Papson, S. (2014). Scholars, Intellectuals, and Bricoleurs. Arts \& Humanities in Higher Education, 13(4), pp. 377-394. DOI: 10.1177/ 1474022213487951.

Phillimore, J., Bradby, H., Doos, L., Padilla, B., \& Samerski, S. (2018). Health Providers as Bricoleurs: An Examination of the Adaption of Health Ecosystems to Superdiversity in Europe. Journal of European Social Policy, 29(3), pp. 361-375. DOI: 10.1177/0958928718795994.

Phillips, N., \& Tracey, P. (2007). Opportunity Recognition, Entrepreneurial Capabilities and Bricolage: Connecting Institutional Theory and Entrepreneurship in Strategic Organization. Strategic Organization, 5(3), pp. 313-320. DOI: 10.1177/ 1476127007079956.

Rubacha, K. (2013). Metodologiczna analiza praktyki badań pedagogicznych. In: T. Bauman (Ed.), Praktyka badań pedagogicznych (pp. 69-81). Kraków: Oficyna Wydawnicza Impuls. 
Russell, R., \& Tyler, M. (2005). Branding and Bricolage: Gender, Consumption and Transition. Childhood, 12(2), pp. 221-237. DOI: 10.1177/0907568205051905.

Sadoń-Osowiecka, T. (2009). Bricolage jako konstruktywistyczne podejście do badań edukacyjnych. Patchwork o bricolage’u. Problemy Wczesnej Edukacji, 5(10), pp. 72-81.

Saroglou, V. (2006). Religious Bricolage as a Psychological Reality: Limits, Structures and Dynamics. Social Compass, 53(1), pp. 109-115. DOI: 10.1177.0037768606061581.

Saumure, K., \& Given, J.M. (2008). Rigor in Qualitative Research. In: L.M. Given (Ed.), The Sage Encyclopedia of Qualitative Research Methods (pp. 795-796). Los Angeles-London-New Delhi-Singapore: Sage.

Snow, Ch.P. (1999). Dwie kultury. Z przedmowq Stefana Colliniego. Warszawa: Wydawnictwo Prószyński i S-ka.

Stinchfield, B.T., Nelson, R.E., \& Wood, M.S. (2013). Learning from Levi-Strauss’ Legacy: Art, Craft, Engineering, Bricolage, and Brokerage in Entrepreneurship. Entrepreneurship Theory and Practice, 37(4), pp. 889-921. DOI: 10.1111/j.1540-6520.2012.00523.x.

Sztompka, P. (1973). Teoria i wyjaśnienie. Z metodologicznych problemów socjologii. Warszawa: PWN.

Tam, P.Ch. (2012). Children's Bricolage under the Gaze of Teachers in Sociodramatic Play. Childhood, 20(2), pp. 244-259. DOI: 10.1177/0907568212461036.

The Ordinance of the Minister of Science and Higher Education of February 22, 2019. https:// tiny.pl/79bhs. [03.01.2020].

Tlili, A. (2016). Encountering the Creative Museum: Museographic Creativeness and the 'Bricolage’ of Time Materials. Educational Philosophy and Theory, 48(5), pp. 443-458. DOI: 10.1080/00131857.2015.1031068.

Turnbull, S. (2002). Bricolage as an Alternative Approach to Human Resource Development Theory Building. Human Resource Development Review, 1(1), pp. 111-128. DOI: 10.117 7/1534484302011006.

Valliere, D., \& Gegenhuber, T. (2014). Entrepreneurial Remixing: Bricolage and Postmodern Resources. Entrepreneurship and Innovation, 15(1), pp. 5-15. https://doi.org/10.5367/ ijei.2014.0141.

Van Mierlo, B., \& Totin, E. (2014). Between Script and Improvisation: Institutional Conditions and Their Local Operation. Agriculture, 43(3), pp. 157-163. DOI: 10.5367/oa.2014.0179.

Visscher, K., Heusinkveld, S., \& O’Mahoney, J. (2018). Bricolage and Identity Work. British Journal of Management, 29(2), pp. 356-372. DOI: 10.1111/1467-8551.12220.

Ward, I. (2008). Bricolage and Low Cunning: Rorty on Pragmatism, Politics and Poetic Justice. Legal Studies, 28(2), pp. 281-305. DOI: 10.1111/j.1748-121X.2008.00088.x.

Weinstein, D., \& Weinstein, M.A. (1991). Georg Simmel: Sociological Flâneur Bricoleur. Theory, Culture \& Society, 8(3), pp. 151-168. DOI: 10.1177/026327691008003011.

Zajda, K. (2017). Bricolage w wykorzystaniu zasobów społecznych wsi. Relacja między zasobami społecznymi obszarów partnerstw a kapitałem społecznym lokalnych grup działania z województw o odmiennych tradycjach społecznikowskich. Studia Obszarów Wiejskich, 46: Społeczne i indywidualne zasoby obszarów wiejskich, pp. 117-129. 


\begin{tabular}{|c|c|c|c|c|c|c|c|c|}
\hline & 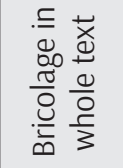 & 으 & $\approx$ & $\stackrel{\infty}{\sim}$ & $\stackrel{\circ}{M}$ & $\hat{M}$ & 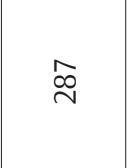 & $\stackrel{\sim}{\vartheta}$ \\
\hline & 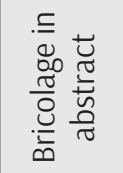 & 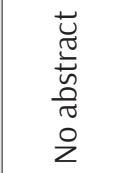 & 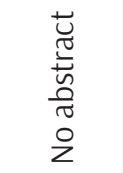 & 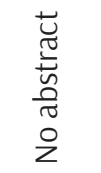 & - & - & 0 & - \\
\hline 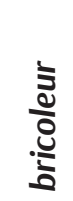 & 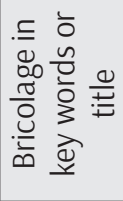 & - & - & - & - & $\sim$ & - & $\sim$ \\
\hline 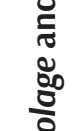 & 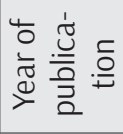 & $\begin{array}{l}\text { ने } \\
\text { தे }\end{array}$ & ঠ̊ & 유 & $\begin{array}{l}\mathcal{N} \\
\stackrel{ }{৩}\end{array}$ & $\begin{array}{l}\text { 오 } \\
\text { ○ }\end{array}$ & 농 & 농 \\
\hline 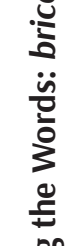 & 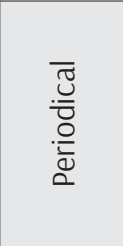 & 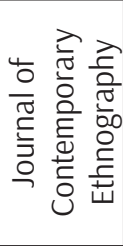 & 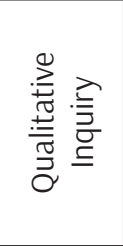 & 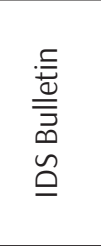 & 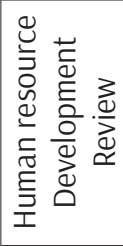 & 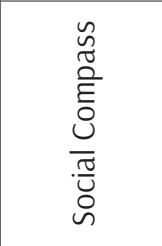 & 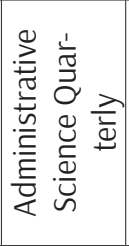 & $\begin{array}{l}\text { ㅁ } \\
\frac{0}{\frac{1}{0}} \\
\frac{\bar{C}}{\mathrm{C}}\end{array}$ \\
\hline 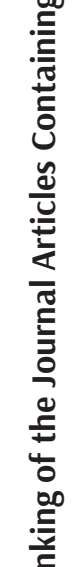 & $\stackrel{0}{\underline{E}}$ & 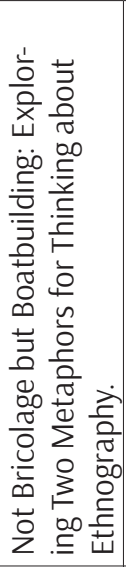 & 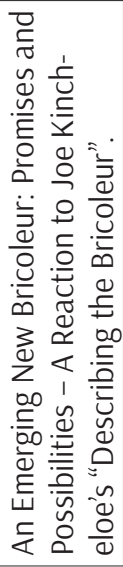 & 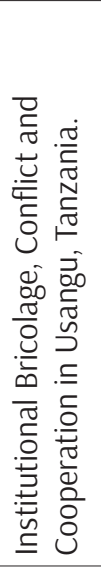 & 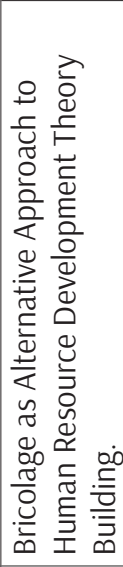 & 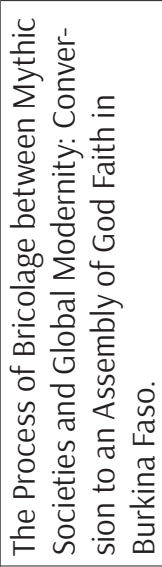 & 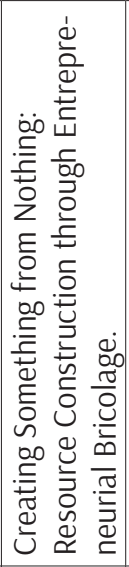 & 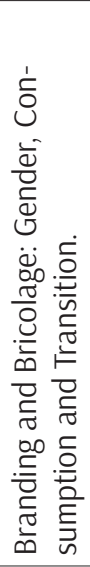 \\
\hline 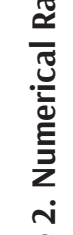 & $\frac{n}{\frac{n}{0}}$ & 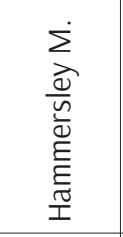 & 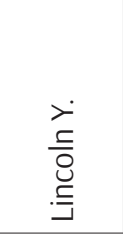 & 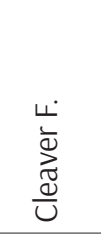 & 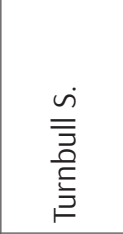 & 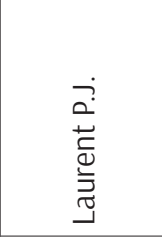 & 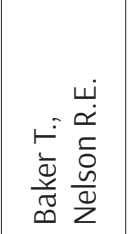 & 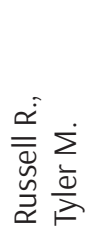 \\
\hline$\frac{\frac{0}{0}}{\frac{0}{\sigma}}$ & í & - & $\sim$ & $M$ & $\triangleleft$ & Ln & 0 & $\Lambda$ \\
\hline
\end{tabular}




\begin{tabular}{|c|c|c|c|c|c|c|c|c|}
\hline 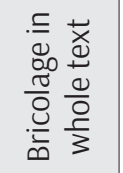 & 유 & $\bullet$ & જ & $\stackrel{\circ}{M}$ & $\stackrel{\circ}{M}$ & $\hat{\sim}$ & $\stackrel{\vec{M}}{ }$ & $\sigma$ \\
\hline 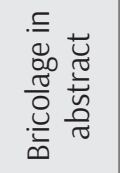 & 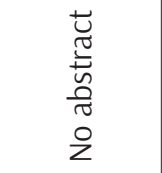 & - & $\sim$ & - & - & 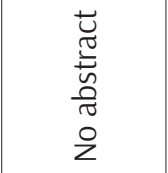 & - & 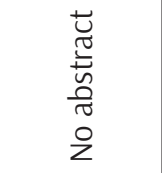 \\
\hline 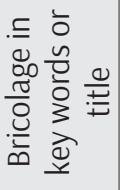 & - & $\sim$ & $\sim$ & - & $\sim$ & - & $\sim$ & - \\
\hline 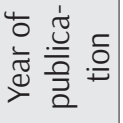 & 뉴 & $\stackrel{\text { L̊ }}{\stackrel{2}{\sim}}$ & $\begin{array}{l}\text { 오 } \\
\stackrel{ }{\nu}\end{array}$ & $\begin{array}{l}0 \\
\stackrel{\circ}{ } \\
\text { ㅇ }\end{array}$ & 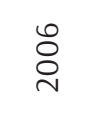 & $\begin{array}{l}0 \\
\stackrel{ᄋ}{ } \\
\text { ㅇ }\end{array}$ & 옹 & ঠ̊̊ి \\
\hline 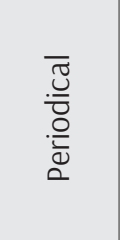 & 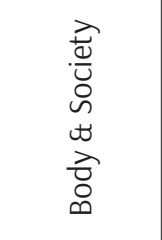 & 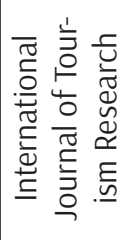 & 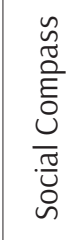 & 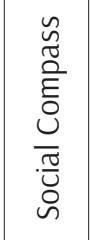 & 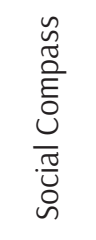 & 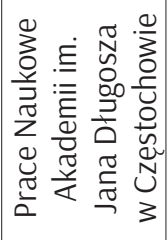 & 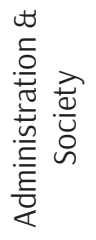 & 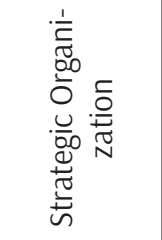 \\
\hline$\stackrel{\text { 岸 }}{\underline{E}}$ & 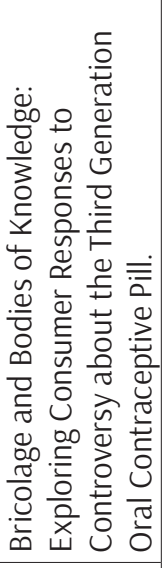 & 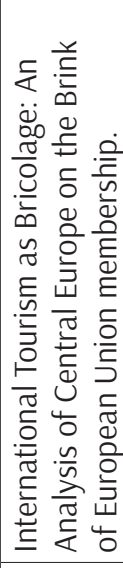 & 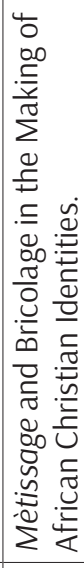 & 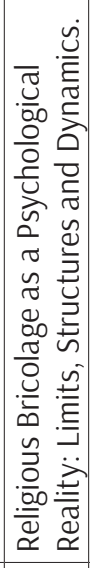 & 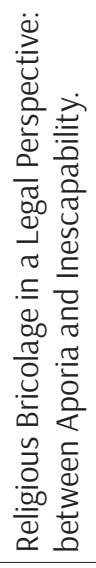 & 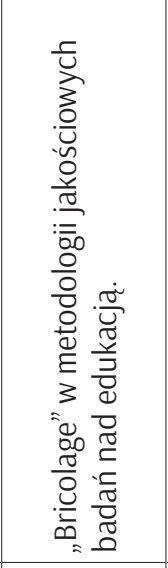 & 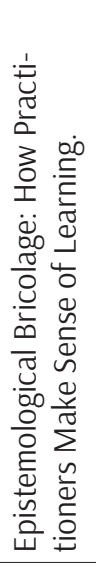 & 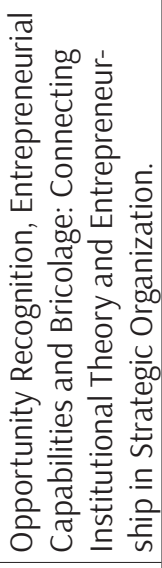 \\
\hline $\begin{array}{l}\frac{n}{0} \\
\frac{0}{ \pm} \\
\frac{1}{2}\end{array}$ & 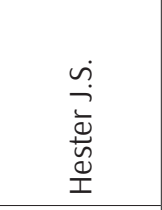 & 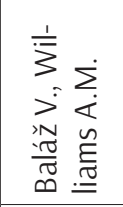 & $\frac{\dot{\Sigma}}{\underset{\frac{\pi}{0}}{\Sigma}}$ & $\begin{array}{l}> \\
\overline{0} \\
0 \\
00 \\
0 \\
0 \\
\tilde{n}\end{array}$ & 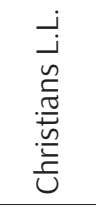 & 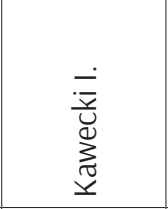 & 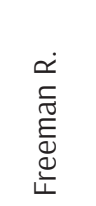 & 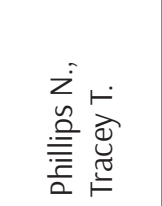 \\
\hline 울 & $\infty$ & $a$ & 으 & $\approx$ & $\stackrel{\simeq}{ }$ & $\stackrel{M}{L}$ & $\Xi$ & $\stackrel{ㄴ}{\sim}$ \\
\hline
\end{tabular}




\begin{tabular}{|c|c|c|c|c|c|c|c|c|}
\hline 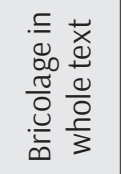 & 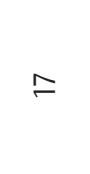 & $\stackrel{\llcorner}{M}$ & N & $\hat{尺}$ & $\hat{M}$ & $\stackrel{\varrho}{\varrho}$ & $\stackrel{M}{M}$ & $\bar{\beth}$ \\
\hline 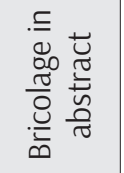 & - & $\forall$ & $\sim$ & $\Lambda$ & $\sim$ & $\forall$ & $M$ & $\sim$ \\
\hline 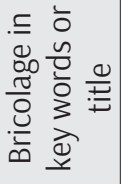 & - & $\stackrel{?}{2}$ & - & $\sim$ & $\sim$ & - & $\sim$ & - \\
\hline 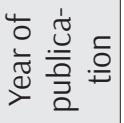 & $\begin{array}{l}\infty \\
\stackrel{2}{\circ} \\
\text { ㄱ }\end{array}$ & $\begin{array}{l}\text { ᄋ } \\
\text { ᄋ }\end{array}$ & $\begin{array}{l}\text { 尺े } \\
\text { ஓ }\end{array}$ & $\stackrel{\circ}{\circ}$ & $\stackrel{\circ}{\stackrel{\nu}{0}}$ & $\stackrel{\circ}{\stackrel{2}{0}}$ & 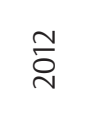 & $\stackrel{\overbrace{}}{\check{\nu}}$ \\
\hline $\begin{array}{l}\overline{ } \\
\frac{0}{0} \\
\frac{0}{\bar{d}} \\
\square\end{array}$ & 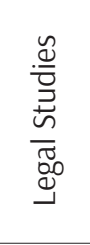 & 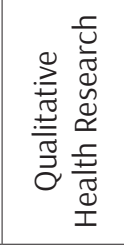 & 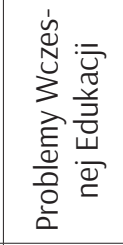 & 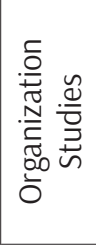 & 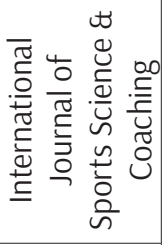 & 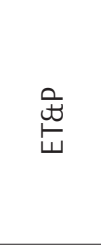 & $\begin{array}{l}\frac{}{8} \\
\frac{0}{\bar{y}} \\
\frac{0}{\bar{C}} \\
\frac{\cup}{U}\end{array}$ & $\stackrel{\stackrel{\varpi}{匕}}{\square}$ \\
\hline 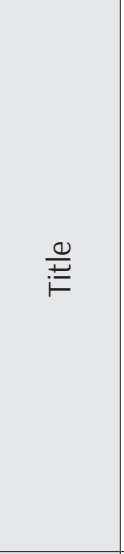 & 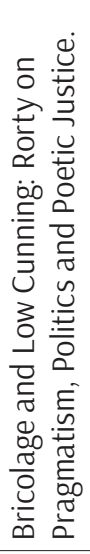 & 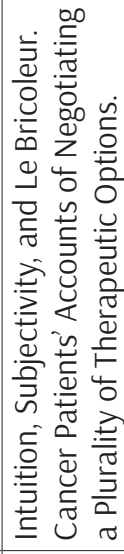 & 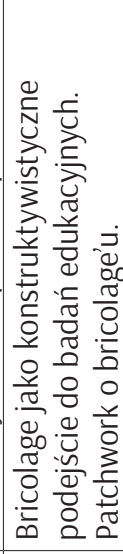 & 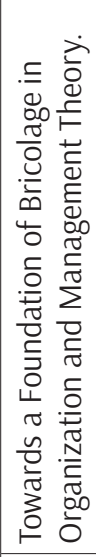 & 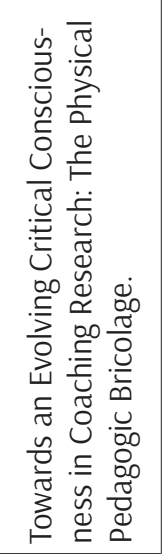 & 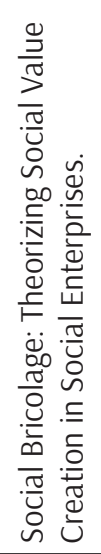 & 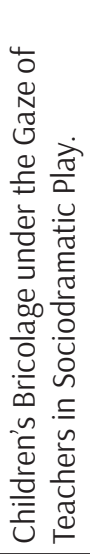 & 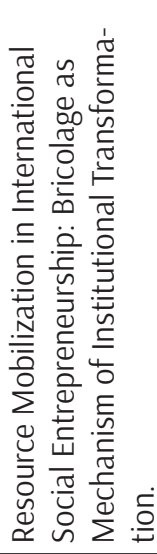 \\
\hline $\begin{array}{l}\frac{n}{0} \\
\frac{1}{5} \\
\frac{3}{2}\end{array}$ & $\begin{array}{l}\frac{\dot{0}}{0} \\
\frac{0}{3} \\
3\end{array}$ & $\begin{array}{l}\dot{⿺} \\
\check{\Xi} \\
\stackrel{0}{\emptyset}\end{array}$ & 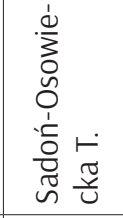 & 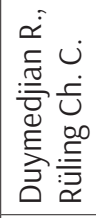 & 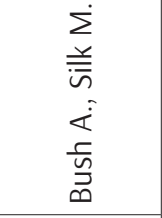 & 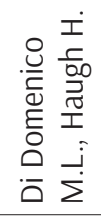 & 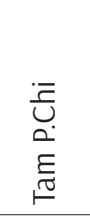 & $\begin{array}{l}\dot{\Xi} \\
\stackrel{0}{0} \\
0\end{array}$ \\
\hline í & 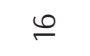 & $\stackrel{ }{=}$ & $\stackrel{\infty}{\sim}$ & $\stackrel{\Omega}{\square}$ & ㄱ & $\bar{\sim}$ & సี & $\stackrel{M}{\sim}$ \\
\hline
\end{tabular}




\begin{tabular}{|c|c|c|c|c|c|c|c|c|}
\hline 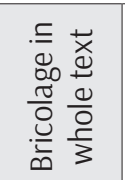 & ন & $\stackrel{\circ}{\circ}$ & $\stackrel{P}{R}$ & $\underset{\forall}{\triangleleft}$ & $\stackrel{\llcorner}{\mathrm{L}}$ & $\stackrel{\stackrel{M}{\sim}}{ }$ & 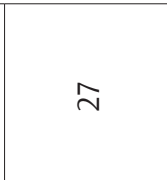 & 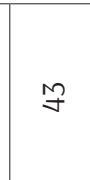 \\
\hline 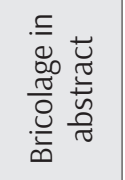 & - & $\sim$ & $\sim$ & $\triangleleft$ & $\triangleleft$ & $\sim$ & - & - \\
\hline 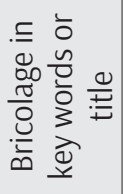 & - & $\sim$ & - & $\sim$ & $\sim$ & $\sim$ & $\sim$ & $\sim$ \\
\hline 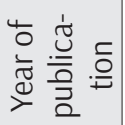 & ָָ & 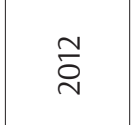 & $\stackrel{\text { ñ }}{\sigma}$ & $\stackrel{+}{\stackrel{D}{v}}$ & $\stackrel{\nabla}{\grave{\nu}}$ & $\underset{⿱ 亠}{\stackrel{D}{v}}$ & $\stackrel{\text { Ln }}{\stackrel{\nu}{v}}$ & $\stackrel{n}{\stackrel{n}{\nu}}$ \\
\hline $\begin{array}{l}\overline{\widetilde{U}} \\
\frac{\bar{n}}{\overline{0}} \\
\bar{\alpha}\end{array}$ & 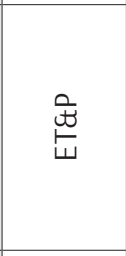 & 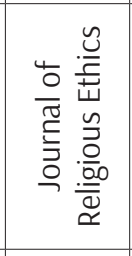 & 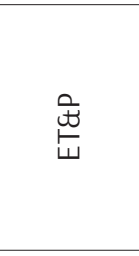 & 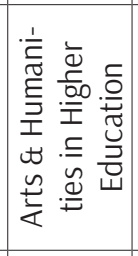 & 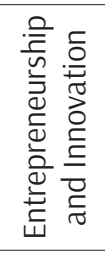 & 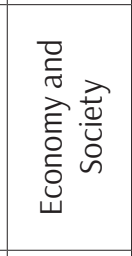 & 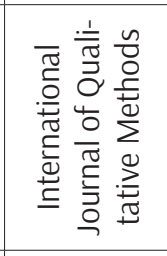 & 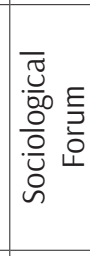 \\
\hline$\stackrel{0}{\stackrel{\Perp}{*}}$ & 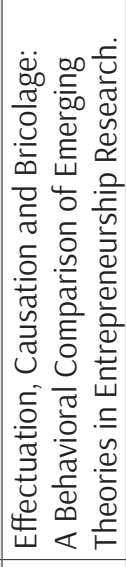 & 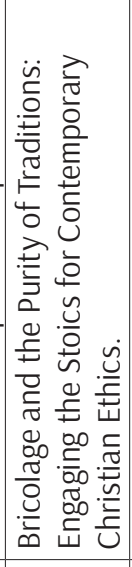 & 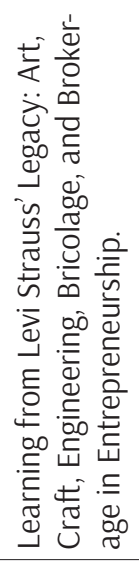 & 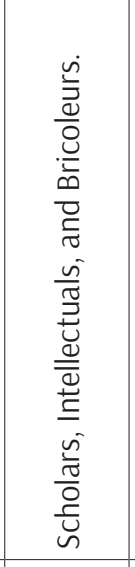 & 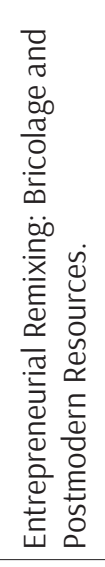 & 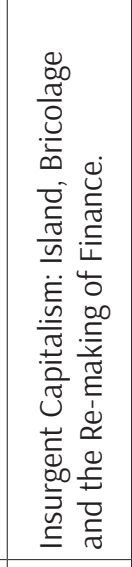 & 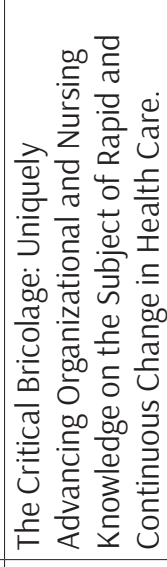 & 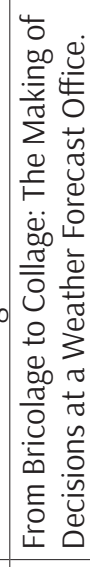 \\
\hline $\begin{array}{l}\frac{n}{0} \\
\frac{1}{ \pm} \\
\frac{1}{4}\end{array}$ & $\begin{array}{l}\dot{\Xi} \\
\frac{\bar{d}}{\bar{n}} \\
\frac{5}{4}\end{array}$ & 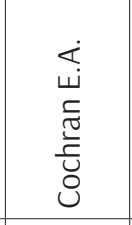 & 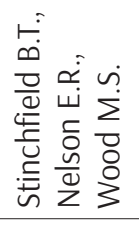 & $\begin{array}{l}\dot{v} \\
\tilde{0} \\
\tilde{0} \\
\tilde{\sigma}\end{array}$ & 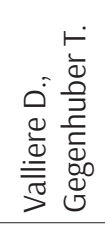 & 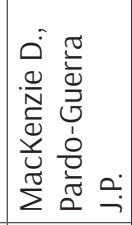 & 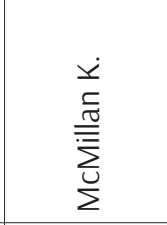 & $\begin{array}{l}0 \\
\frac{0}{0} \\
\frac{0}{\overline{0}} \\
0\end{array}$ \\
\hline$\dot{2}$ & $\nexists$ & $\stackrel{\llcorner}{\sim}$ & $\stackrel{\sim}{\sim}$ & $\hat{\sim}$ & $\stackrel{\infty}{\sim}$ & શ & $\stackrel{\circ}{\mathrm{m}}$ & $\bar{m}$ \\
\hline
\end{tabular}




\begin{tabular}{|c|c|c|c|c|c|c|c|c|c|}
\hline 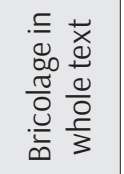 & $\nexists$ & 今 & $\stackrel{৩}{\sim}$ & $\bar{v}$ & $\stackrel{ }{\circ}$ & $\stackrel{\circ}{M}$ & $\gtrsim$ & $\hat{\jmath}$ & in \\
\hline 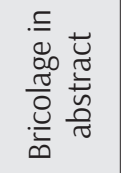 & - & - & $\sim$ & $\sim$ & 0 & - & $\sim$ & $\sim$ & $\sim$ \\
\hline 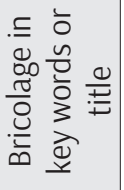 & - & $\sim$ & $\sim$ & 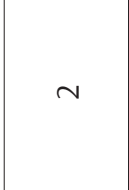 & - & 0 & - & $\sim$ & $\sim$ \\
\hline 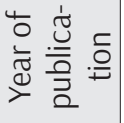 & $\stackrel{\circ}{\frac{0}{\sigma}}$ & $\stackrel{\bullet}{\stackrel{\nu}{\nu}}$ & $\stackrel{0}{\circ}$ & $\stackrel{ }{\circ}$ & 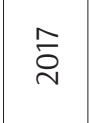 & స̄ & 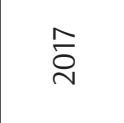 & స̄ & 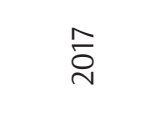 \\
\hline $\begin{array}{l}\overline{ } \\
\frac{0}{0} \\
\frac{0}{\bar{d}} \\
\square\end{array}$ & 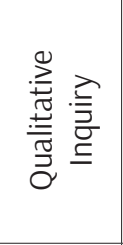 & 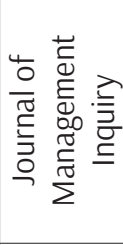 & 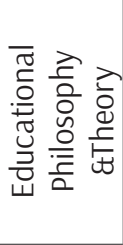 & 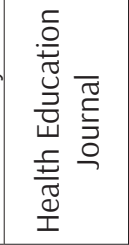 & 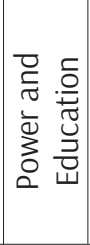 & 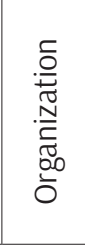 & 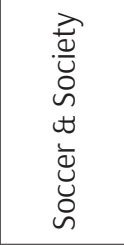 & 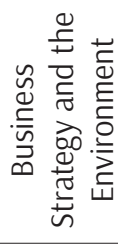 & $\begin{array}{l}\stackrel{\bigcup}{\cong} \\
\models\end{array}$ \\
\hline 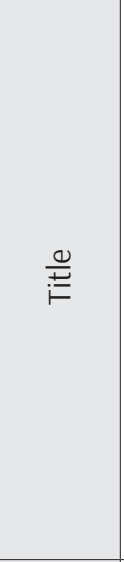 & 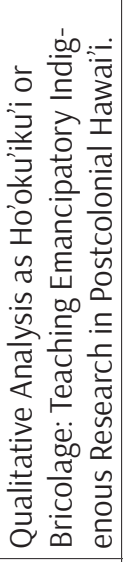 & 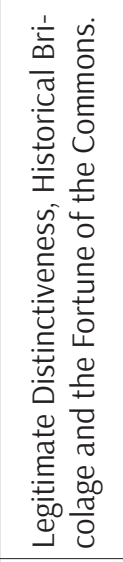 & 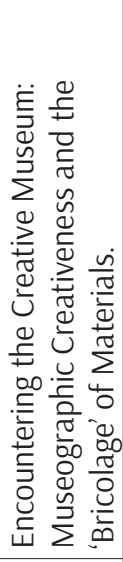 & 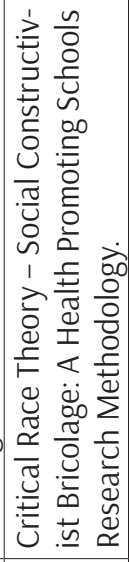 & 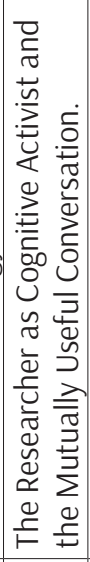 & 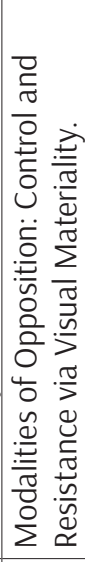 & 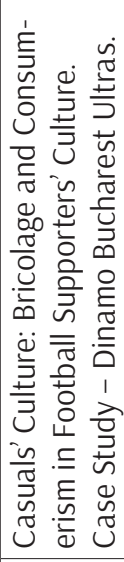 & 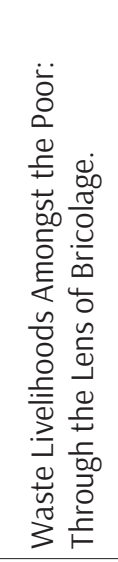 & 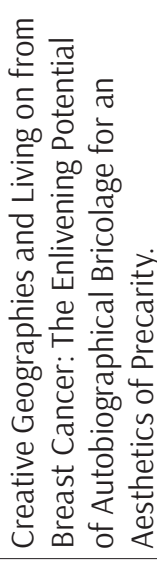 \\
\hline $\begin{array}{l}\frac{n}{0} \\
\frac{1}{5} \\
\frac{3}{2}\end{array}$ & 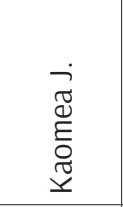 & 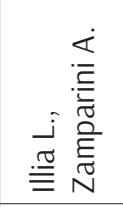 & 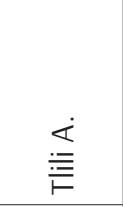 & 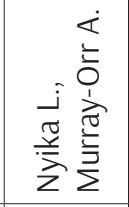 & $\frac{\cup}{\frac{\cup}{ \pm}}$ & 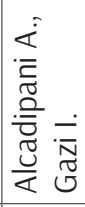 & 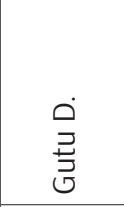 & 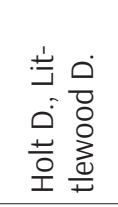 & 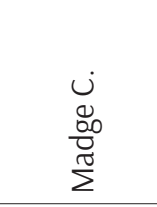 \\
\hline í & N & $M$ & M & $\stackrel{\llcorner}{M}$ & $\stackrel{\bullet}{M}$ & $\hat{M}$ & $\stackrel{\infty}{M}$ & $\stackrel{\mathrm{M}}{ }$ & $\stackrel{\bigcirc}{9}$ \\
\hline
\end{tabular}




\begin{tabular}{|c|c|c|c|c|c|c|c|}
\hline 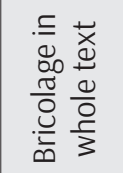 & $\lesssim$ & $\stackrel{\ominus}{q}$ & $\stackrel{M}{ }$ & $\Xi$ & $\bar{\beth}$ & 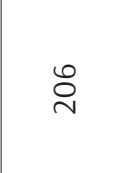 & $\stackrel{\infty}{\sim}$ \\
\hline 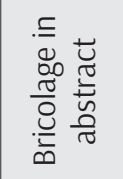 & $\sim$ & - & - & $\wedge$ & 0 & $\stackrel{\circ}{\circ}$ & $M$ \\
\hline 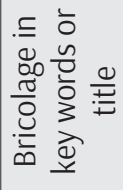 & - & $\sim$ & $\sim$ & $\sim$ & - & - & $\sim$ \\
\hline 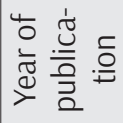 & స̄ & $\stackrel{\infty}{\stackrel{\wp}{\sigma}}$ & $\stackrel{\infty}{\stackrel{\wp}{\sigma}}$ & $\stackrel{\infty}{\stackrel{\infty}{\sim}}$ & $\stackrel{\infty}{\stackrel{\sim}{\nu}}$ & $\stackrel{\infty}{\grave{\nu}}$ & $\stackrel{\sigma}{\frac{\sigma}{N}}$ \\
\hline 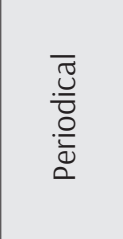 & 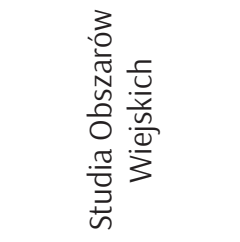 & 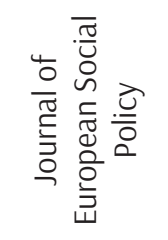 & 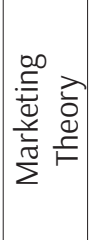 & 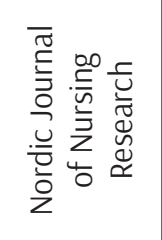 & 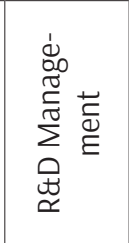 & 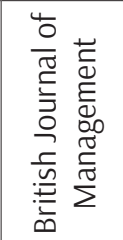 & 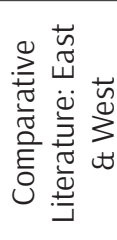 \\
\hline$\stackrel{\stackrel{\varphi}{E}}{\underline{E}}$ & 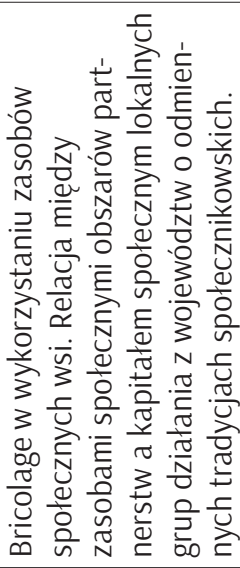 & 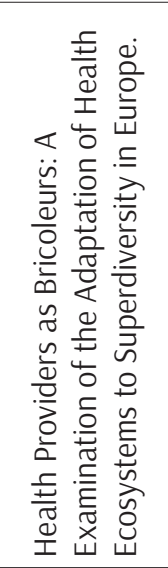 & 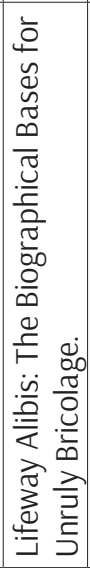 & 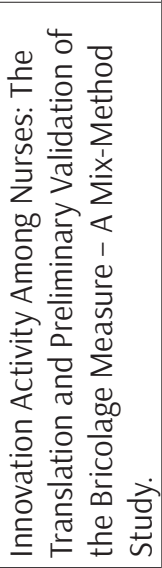 & 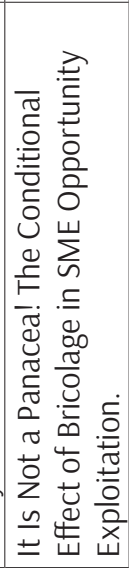 & 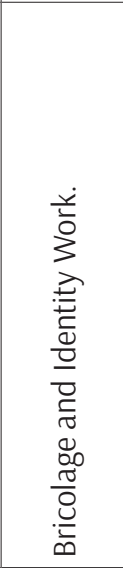 & 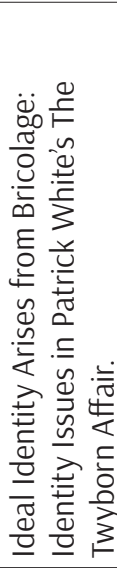 \\
\hline $\begin{array}{l}\frac{n}{0} \\
\frac{1}{5} \\
\frac{3}{2}\end{array}$ & $\begin{array}{l}\frac{\dot{x}}{\tilde{J}} \\
\frac{\pi}{N}\end{array}$ & 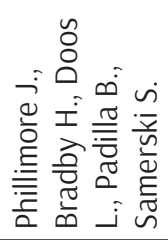 & 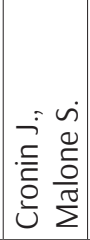 & 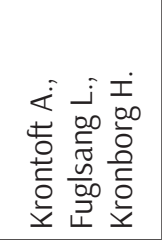 & 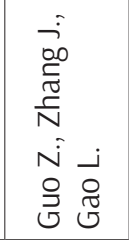 & 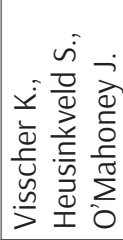 & $\dot{\grave{\Xi}}$ \\
\hline i̊ & $\bar{y}$ & $\stackrel{\Re}{\Im}$ & 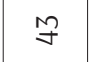 & $\underset{\forall}{\triangleleft}$ & $\stackrel{\stackrel{n}{f}}{*}$ & $\stackrel{\circ}{\sim}$ & ક \\
\hline
\end{tabular}


STATEMENTS - DISCUSSIONS 
